\title{
Persepsi Siswa terhadap Pembelajaran e-Learning melalui Media Google Classroom untuk Meningkatkan Minat Belajar Siswa SMP Negeri 1 Kuok
}

\author{
Melma Rohani ${ }^{1 *}$, Zulfah $^{2}$ \\ ${ }^{1,2}$ Universitas Pahlawan Tuanku Tambusai \\ *)rohanimelma@gmail.com
}

\begin{abstract}
Abstrak
Penelitian ini bertujuan untuk mendeskripsikan penerapan e-learning dengan media aplikasi Google Classroom dalam meningkatkan minat belajar siswa kelas IX SMPN 1 Kuok tahun ajaran 2019/2020 dan meningkatkan minat belajar siswa melalui penerapan E-Learning dengan media Google Classroom kelas IX SMPN 1 Kuok tahun ajaran 2019/2020. Penelitian ini merupakan penelitian tindakan kelas (PTK) yang terdiri dari satu siklus. Subjek penelitian ini adalah seluruh siswa kelas IX SMPN 1 Kuok yang berjumlah 20 siswa. Teknik pengumpulan data meliputi observasi, tes, dan dokumentasi. Teknik analisis data menggunakan analisis data deskriptif kualitatif. Hasil penelitian menunjukkan bahwa minat belajar siswa dengan menggunakan pembelajaran e-learning melalui google classroom memiliki 4 aspek, yaitu: aspek perasaan senang sebanyak $60 \%$ dengan kategori senang, ketertarikan siswa sebanyak 50\% dengan kategori kuat, perhatian siswa sebanyak $40 \%$ dengan kategori sangat kuat, dan terlibat aktif sebanyak $50 \%$ dengan kategori kuat.
\end{abstract}

Kata Kunci: E-Learning, google classroom, minat belajar.

\begin{abstract}
The research is intended to: 1) describe the application if an e-application with media Classroom Google applications increase classroom interest in studying class IX SMPN 1 Kuok year 2019/2020, 2) increasing students interest in learning through application of e-learning with the Google Classroom IX SMPN 1 Kuok year 2019/2020. This study is a one-cycle class action study (PTK). The subject of this study is total number of students in IX SMPN 1 class of 20 students. Data collection techniques include observation, testing, and documentation. Data analysis techniques using kualitative descriptive data analysis research shows that students interest in learning through Google Classroom study has 4 aspects, which are:1) as much fun as 60\% with a happy category, 2) students interests as much as 50\% strong, 3) student attentions as $40 \%$ in highly strong categories, and 4) actively engaged as 50\% in strong categories.
\end{abstract}

Keywords: E-Learning, google classroom, learing interest

\section{Pendahuluan}

Pandemi COVID-19 adalah krisis kesehatan yang pertama dan terutama di dunia. Banyak negara memutuskan untuk menutup sekolah, perguruan tinggi dan universitas. Perserikatan Bangsa-Bangsa (PBB) menjaaddi gusar dengan adanya fakta tersebut. Organisasi Internasional yang bermarkas di New York, AS, itu menangkap bahwa pendidikan menjadi salah satu sektor yang begitu terdampak oleh virus corona. Parahnya lagi, hal itu terjadi dalam tempo yang cepat dan skala yang luas. Berdasarkan laporan $\mathrm{ABC}$ News 7 Maret 2020, penutupan sekolah terjadi di lebih dari puluhan negara karena wabah 
COVID-19. Menurut data Organisasi Pendidikan, Keilmuan, dan Kebudayaan PBB (UNESCO), setidaknya ada 290,5 juta siswa di seluruh dunia yang aktivitas belajarnya menjadi terganggu akibat sekolah yang ditutup.

Penyebaran virus corona ini pada awalnya sangat berdampak pada dunia ekonomi yang mulai lesu, tetapi kini dampaknya dirasakan juga oleh dunia pendidikan. Kebijakan yang diambil oleh banyak negara termasuk Indonesia dengan meliburkan seluruh aktivitas pendidikan, membuat pemerintah dan lembaga terkat harus menghadirkan alternatif proses pendidikan bagi peserta didik maupun mahasiswa yang tidak melaksanakan proses pendidikan pada lembaga pendidikan.

Menurut Dewi (2019) Pendidikan pada hakikatnya adalah sebuah proses untuk menyiapkan manusia agar dapat bertahan hidup dalam lingkungannya (life skill). Menurut Septian (2020) Pendidikan merupakan media yang memiliki peranan penting untuk membantu manusia dalam mengembangkan potensi dirinya, melalui pendidikan akan terjadi proses pemberdayaan manusi menjadi sumber daya yang berkualitas. Untuk meningkatkan kualitas sumber daya manusia maka diperlukan pendidikan yang baik dan tepat (Ulfa, 2019).

Menurut Hamimi (2020) perkembangan guru sebagai tokoh pendidikan utama mempunyai peranan penting atas maju mundurnya pendidikan. Berdasarkan hal tersebut, guru dituntut untuk dapat melaksanakan serta mengolah pendidikan selaras dengan pendidikannya. Sebagai guru yang baik, guru senantiasa harus memperhatikan siswanya untuk melihat perubahan yang terjadi selama dan setelah proses pembelajaran terjadi.

Pembelajaran e-learning sekarang menjadi pilihan utama karena adanya pandemi ini. Pembelajaran e-learning adalah suatu pendekatan pembelajaran yang pada pelaksanaannya tidak bertatap muka langsung di kelas. E-learning bisa digunakan dalam kondisi seperti ini, karena berbasis internet yang berarti tidak perlu datang ke kelas (Yaumi, 2007), salah satu alat yang dipakai adalah google classroom. Oleh karena itu, elearningsemakin menjadi pilihan karena dapat menghemat biaya, waktu, dan fleksibel (Kusuma, dkk, 2008).

Pembelajaran dengan menggunakan kemajuan teknologi ini dapat memberikan pengaruh yang signifikan terhadap dunia pendidikan untuk menunjang kegiatan proses pembelajaran. Penguasaan guru dan siswa di dalam menggunakan TIK pun menjadi hal yanng sangat penting dalam rangka menghadapi persaingan global yang menuntut siswa untuk memiliki minat di dalam belajar sehingga mampu untuk mandiri, kreatif, berfikir 
kritis, dan mampu memecahkan masalah sesuai tuntutan abad 21 mengunakan pembelajaran berbasis teknologi. Hal ini sejalan dengan penelitian Saputra\&Febriyanto (2019) mengatakan bahwa perkembangan teknologi dapat dijadikan solusi untuk berinovasi dalam bidang pembelajaran khususnya dalam pembuatan dan pengembangan media pembelajaran agar dalam proses pembelajaran lebh menarik yang berdampak pada minat belajar siswa.

Pembelajaran e-learning merupakan satu solusi solusi untuk memecahkan masalah yang bisa dilaksanakan guru dalam proses pembelajaran. Pembelajaran e-learning dapat melatih siswa untuk belajar mandiri sehingga dapat membuat dirinya memiliki minat dalam belajar. Selain itu, siswa dapat memperkuat pengetahuannya dengan cara mencari sendiri pengetahuan yang mereka butuhkan melalui fasilitas internet dengan arahan guru.

Minat belajar sangat penting dalam proses pembelajaran, karena minat merupakan salah satu faktor internal yang mempengaruhi pembelajaran. Slameto (2010) menjelaskan bahwa minat adalah suatu kecenderungan tetap pada seseorang untuk memperhatikan suatu kegiatan yang disukai sehingga mampu memperhatikan secara terus-menerus, puas dan ketertarikan pada suatu hal atau aktivitas, tanpa adanya suruhan dari orang lain. Di dalam pembelajaran, ketika siswa tidak berminat untuk belajar, maka akan menimbulkan suasana pembelajaran yang tidak kondusif. Minat belajar menurut Qomariah dan Ketut (2016) merupakan perasaan suka atau ketertarikan peserta didik terhadap pelajaran sehingga mendorongnya untuk mempelajari dan menguasai pengetahuan serta pengalaman dengan ditunjukkan melalui partisipasi dan keaktifan dalam mencari pengetahuan dan pengalaman tersebut. Oleh karena itu, minat belajar akan mendorong siswa untuk belajar lebih baik lagi dengan adanya ketertarikan atau suka pada pelajaran sehingga memiliki inisiatif untuk terus belajar dan merasa sangat bermanfaat baginya.

Kegiatan belajar mengajar akan berjalan secara efektif dan efisien jika siswa memiliki minat yang tinggi untuk belajar. Indikator minat belajar menurut Djamarah (2011) terdiri dari: 1) Perasaan senang terhadap suatu kegiatan tanpa paksaan untuk mempelajarinya, 2) Ketertarikan siswa pada kegiatan atau bisa berupa pengalaman yang dirangsang oleh kegiatan itu sendiri, 3) Perhatian siswa dengan melakukan konsentrasi atau aktivitas terhadap pengamatan tertentu, 4) Keterlibatan siswa pada suatu objek yang mengakibatkan orang tersebut senang untuk belajar dan merasa tertarik untuk melakukan atau mengerjakan kegiatan pembelajaran yang diberikan. 
Istiqomah\&Ninik (2013) menjelaskan bahwa salah satu yang dapat meningkatkan minat belajar siswa adalah penggunaan metode pembelajaran yang tepat. Misalnya, guru memanfaatkan penggunaan internet di dalam pembelajaran. Oleh karena itu, perlu diupayakan terobosan pembelajaran untuk meningkatkan minat belajar siswa melalui penggunaan media pembelajaran berbasis e-learning. Salah satunya adalah dengan menggunakan media google classroom.

Izenstark dan Leahy (2015) menjelaskan bahwa desain dari google classroom sudah tidak asing lagi bagi siswa karena mereka sudah menggunakan beberapa produk dari google via akun. Google Apps memiliki konektivitas antara google classroom dengan akun google drive sehingga tidak perlu khawatir untuk menyimpan dokumen-dokumen dalam komputer. Dalam proses pembelajaran pun siswa diberikan penugasan oleh guru dan mengirimkan hasil laporannya ke aplikasi google classroom. Selain itu, siswa diberikan materi tambahan guna memahami lebih luas materi yang mungkin belum bisa tersampaikan langsung ketika di kelas.

Kelebihan google classroom menurut Janzem dalam Iftakhar (2016) yaitu mudah digunakan, dapat menghemat waktu, berbasis cloud, bersifat fleksibel kapan saja dan dimana saja bisa digunakan, dan tidak berbayar (gratis). Sedangkan kelemahannya tidak ada layanan eksternal seperti bank soal secara otomatis dan obrolan secara pribadi antara guru dan siswa untuk mendapat umpan balik (Pappas, 2015).

SMP N 1 Kuok merupakan salah satu sekolah yang telah memanfaatkan e-learning sebagai media pembelajaran pada kondisi saat ini yaitu adanya Covid-19. Kegiatan pembelajaran di sekolah tersebut menggunakan media e-learning dengan memanfaatkan aplikasi google classroom. Dalam proses pembelajarannya siswa diberikan penugasan oleh guru dan mengirim hasilnya ke aplikasi tersebut.

Berdasarkan permasalahan dan kondisi diatas, maka peneliti tertarik untuk melakukan pengkajian lebih mendalam mengenai minat belajar siswa dengan menggunakan pembelajaran e-learning melalui Google Classroom di SMPN 1 Kuok.

\section{Metode Penelitian}

Jenis penelitian yang dilakukan adalah penelitian tindakan kelas (PTK) yang fokus utamanya adalah meningkatkan minat belajar siswa dilihat dari keterlibatan siswa dengan penggunaan aplikasi Google Classroom. Tempat penelitian dilakukan di SMP N 1 Kuok.Populasi dalam penelitian ini adalah siswa kelas IX SMPN 1 Kuok tahun pelajaran 
2019/2020. Pengambilan sampel dilakukan dengan menggunakan teknik random sampling, dimana sampel yang terpilih adalah siswa kelas IX A SMPN 1 Kuok tahun pelajaran 2019/2020. Sampel dalam penelitian ini berjumlah 10 orang yang terdiri atas perempuan 7 orang dan laki-laki 3 orang.

Tabel 1. Profil Responden

\begin{tabular}{|c|c|}
\hline Nama & Jenis Kelamin \\
\hline Diva Fitri Angeliani Windra & Wanita \\
\hline Priska Wahyu Ilahi & Wanita \\
\hline Putri & Wanita \\
\hline Wawan Aditia & Pria \\
\hline Raka Ferdinan & Pria \\
\hline Astri & Wanita \\
\hline Kasmida Melati & Wanita \\
\hline Rohana & Wanita \\
\hline Nugi Saputra & Wanita \\
\hline Ando & Pria \\
\hline
\end{tabular}

Pengumpulan data dalam penelitian ini adalah angket untuk mendapatkan data minat belajar siswa. Hasil minat belajar siswa menggunakan rumus presentase dari hasil pengumpulan data menggunakan angket. Angket yang diberikan digunakan untuk mengetahui minat siswa mengenai pembelajaran e-learning. Angket berupa angket terbuka yang dapat memberi kebebasan bagi siswa untuk memberikan jawaban atau tanggapan. Angket tersebut berupa angket respon siswa setelah mengikuti model pembelajaran $e$ learning. Teknik pengumpulan data menggunakan kusioner.

\section{Tabel 2. Rentang Skala Tingkat Capaian Responden}

\begin{tabular}{|c|c|c|}
\hline No & Angka & Keterangan \\
\hline 1 & $00 \%-20 \%$ & Sangat Lemah \\
\hline 2 & $21 \%-40 \%$ & Lemah \\
\hline 3 & $41 \%-60 \%$ & Cukup \\
\hline 4 & $61 \%-80 \%$ & Kuat \\
\hline 5 & $81 \%-100 \%$ & Sangat Kuat \\
\hline
\end{tabular}

Diadopsi dari Ridwan (2006)

\section{Hasil dan Pembahasan}

Tujuan dari penelitian ini adalah untuk mendapatkan informasi mengenai dampak dari pandemi COVID-19 terhadap minat belajar siswa melalui pembelajaran e-learning dengan aplikasi google classroom di kelas IX SMPN 1 Kuok. Semua tanggapan siswa adalah kutipan asli, dan telah dikutip sebagaimana dinyatakan oleh para responden.

Seorang dari responden memberikan pernyataan : 
"Dengan diterapkannya pembelajaran e-learning memaksa orang tua untuk terlibat langsung dalam kegiatan belajar mengajar anaknya”.(Rohana)

Responden lain memberikan pernyataan sebagai berikut:

"Dampak dari pembelajaran e-learning ini bagi siswa dan siswa adalah tidak dapat memperoleh pendidikan di luar rumah atau lebih tepatnya di sekolah, karena bagaimanapun juga akan lebih baik jika dilakukan di sekolah. Walaupun sekarang sudah ada proses belajar online, tapi itu membuat siswa/i tidak bisa berinteraksi langsung dengan guru mata pelajaran hingga materi yang belum dimengerti akan sedikit sulit untuk dipelajari. (Diva Fitri Angeliani Windra)

Dia juga menambahkan pernyataan bahwa:

"Pandemi ini juga sangat berdampak buruh pada keadaan sosial, mempengaruhi di bidang ekonomi dan juga di bidang pendidikan, karena adanya COVID-19 ini, banyak warung-warung atau usaha-usaha perdagangan ditutup. Tujuan ditutupnya yaitu untuk mengindari keramaian dan mencegah penyebaran virus tersebut. Sementara pengaruh dibidang pendidikan (Diva Fitri Angeliani Windra).

Responden lainnya menambahkan:

"Yang terjadi saat ini sangat mengkhawatirkan, karena sudah banyak masyarakat dan warga Indonesia yang terkena COVID-19 dan mengakibatkan banyak masyarakat yang meninggal dunia dan aktifitas semakin tidak dilakukan di luar rumah. Banyak warga yang pekerjaannya sebagau pedagang aktifitasnya terhenti karena pandemi ini dan pembeli pun tidak bisa mencukupi kebutuhan rumahnya karena dilarang berada ditempat keramaian. Begitupun sekolah, sekolah sekarang tidak lagi diadakan karena takut akan menularnya virus COVID-19 ini.(Priska Wahyuni Ilahi).

Pendapat lain juga diberikan oleh beberapa siswa/i terkait dengan pembelajaran e-learning yang terjadi sampai pada saat ini. Menurut seorang responden memberikan responden bahwa:

"Pembelajaran daring ini siswa kurang dapat memahami setiap materi apa yang dipelajari”.(Astri).

Mirip dengan ini, responden lain juga memberikan pernyataan:

"Untuk pembelajaran e-learning ini saya kurang paham dan kurang menyetujui”. (Nugi Saputra). 
Beberapa pendapat juga diberikan oleh beberapa responden tentang pembelajaran $e$ leaning yang terjadi sampai saat ini diantaranya:

"Sebenarnya belajar daring juga bagus. Sebagai pengalaman baru dan juga dalam metode pembelajaran daring ini, dapat dikerjakan kapan saja jika kita memiliki waktu luang. Tapi yang namanya tugas harus tetap dikerjakan. Kita harus tetap mempunyai waktu untuk mengerjakan tugas-tugas tersebut, karena ini kewajiban kita sebagai pelajar. Hanya saja, jika dibandingkan antara metode pembelajaran daring dengan metode pembelajaran di sekolah, pasti akan lebih menyenangkan untuk belajar di sekolah, karena jika disekolah, kita dapat menanyakan langsung apa yang belum kita mengerti dan mencoba mengerjakannya bersama. Bukankah itu lebih indah? Tapi, ini bukan berarti saya tidak setuju dengan adanya pembelajaran daring. Tetapi, saya hanya menyampaikan pendapat saya. (Diva Fitri Angeliani Windra).

Namun berbeda dengan responden dari Raka Ferdinan:

"Pembelajaran daring harus menggunakan kuota internet yang cukup serta sinyal yang memadai. Jika keduanya tidak tersedia maka terhambatlah proses pembelajaran siswa. (Raka Ferdinan).

Sebanyak 10 responden telah memberikan pernyataan dan pendapat yang akan dijelaskan dan dibahas sebagai berikut.

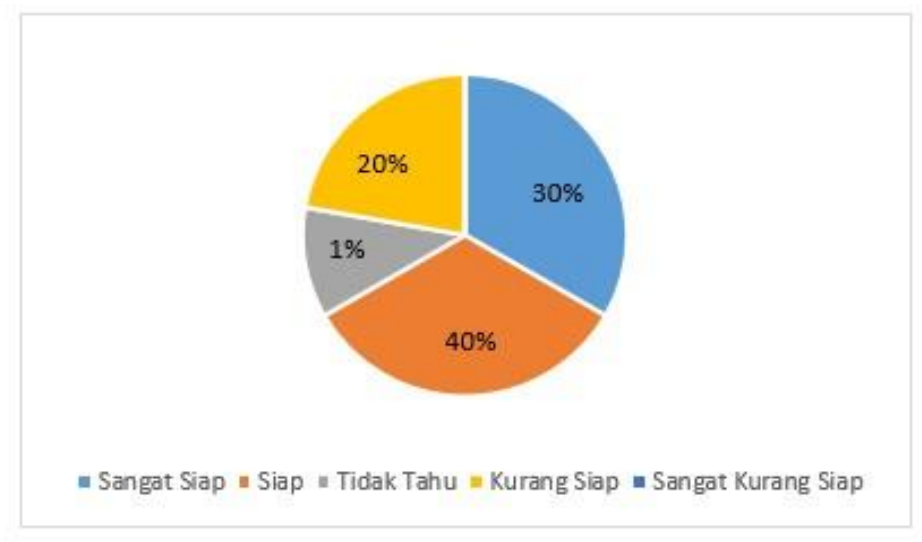

Gambar 1. Rekap Minat Belajar Siswa

Data hasil respon siswa diketahui bahwa dari 10 siswa/i menunjukkan bahwa yang sangat siap melakukan pembelajaran e-learning dengan menggunakan aplikasi google classroom adalah sebanyak $30 \%$, siap sebanyak $40 \%$, tidak tahu sebanyak $10 \%$, dan tidak 
siap sebanyak 20\%. Dari data diatas diketahui bahwa siswa menyetujui pembelajaran $e$ learning saat ini.

Angket minat dalam penelitian ini terdiri dari 4 aspek yaitu: perasaan senang, ketertarikan siswa, perhatian siswa, dan keterlibatan siswa siswa. Aspek tersebut dijabarkan menjadi beberapa indikator (Safari, 2003).

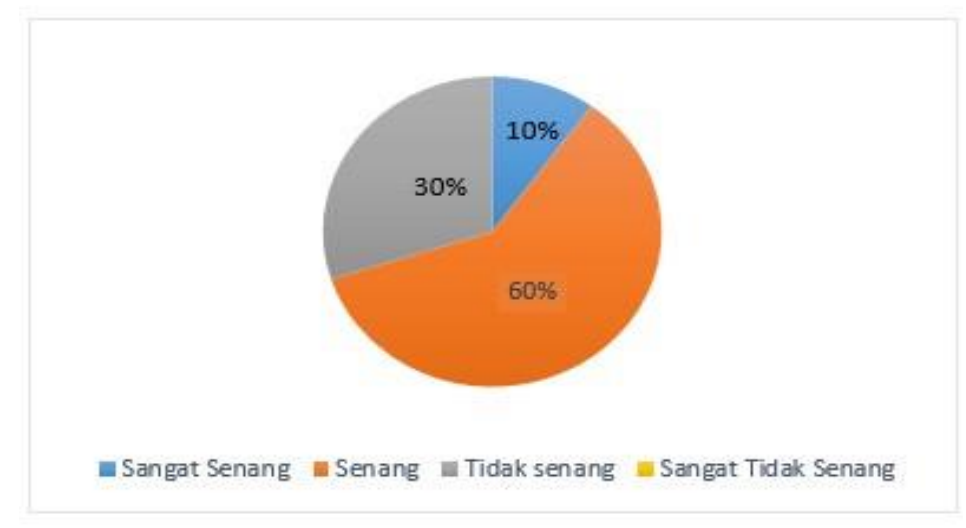

Gambar 2. Respon siswa terhadap e-learning

Indikator perasaan senang siswa. Rata-rata interpretasi perasaan senang siswa belajar dengan menggunakan e-learning melalui google classroom sebesar 10\% dengan kategori sangat senang, 60\% dengan kategori senang, dan 30\% dengan kategori tidak senang. Ini menunjukkan bahwa siswa merasa senang dengan pembelajaran yang dilakukan guru secara tidak langsung dibandingkan dengan bertatap muka langsung. Dengan menggunakan pembelajaran e-learning siswa bisa bertanya dan belajar dari media internet untuk memahami materi yang diberikan guru sehingga dapat menghemat dari segi waktu. Hal ini sesuai dengan penelitian Bibi (2015) yang mengatakan bahwa pelaksanaan e-learning efisien dari segi waktu karena pemberian materi yang diberikan bersifat mandiri bagi siswa.

Berdasarkan hasil wawancara dan observasi dengan beberapa siswa, diperoleh informasi bahwa siswa senang belajar dengan menggunakan e-learning melalui google classroom. Selain itu, pembelajarannya juga tidak menyusahkan, karena siswa dapat dengan mudah mengaksesnya baik dari komputer maupun dari ponsel android dengan bantuan internet sehingga siswa senang apalagi dengan kebiasaan siswa yang tiap hari aktif dengan gadget dan media online. 


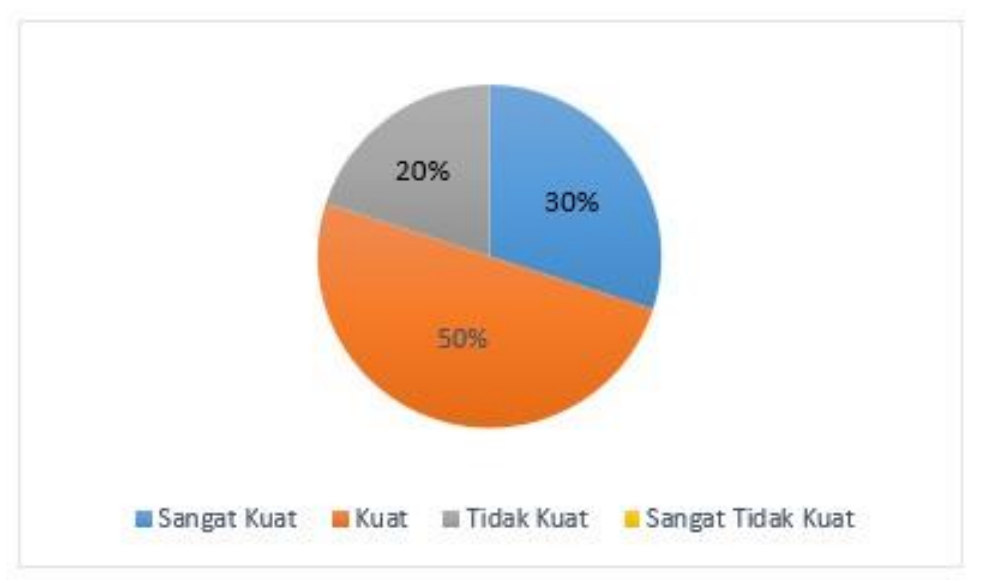

Gambar 3. Respon siswa terhadap e-learing

Indikator ketertarikan siswa dengan menggunakan e-learning melalui google classroom rata-rata interpretasinya sebesar 30\% dengan kategori sangat kuat, 50\% dengan kategori kuat, dan 20\% dengan kategori tidak kuat. Hal ini menunjukkan bahwa siswa yang memberikan ketertarikan terhadap pelajaran yang dilakukan secara daring kuat, bahwa siswa tertarik ketika belajar secara daring melalui google classroom.

Berdasarkan hasil wawancara dengan siswa, menunjukkan bahwa mereka sangat tertarik dengan pembelajaran yang dilakukan secara daring. Hal tersebut sesuai dengan hasil penelitian Gunawan dan Stefani (2018) menjelaskan bahwa pembelajaran dengan menggunakan google classroom secara perlahan akan membuat siswa merasa terbantu untuk memahami materi pembelajaran dikarenakan pembelajaran tidak dibatasi oleh waktu, sehingga siswa dapat belajar pada waktu-waktu tertentu dalam artian tidak terkurung oleh waktu pada saat jam pelajaran, sehingga soal yang dirasakan sulit tersebut dapat dikerjakan dalam waktu yang lebih lama. Hal ini sesuai dengan pendapat Iftakhar (2016) yang menjelaskan bahwa google classroom membantu untuk memonitoring siswa untuk belajar. Guru dapat melihat seluruh aktivitas siswa selama pembelajaran di google classroom. Interaksi antara guru dan siswa terekam dengan baik sehingga mempermudah untuk mengetahui diskusi yang dilakukan di dalam classroom.

Gunawan dan Stefani (2018) menjelaskan bahwa pembelajaran dengan menggunakan google classroom akan efektif karena dapat melihat tingkat kesalahan yang dibuat oleh siswa saat menyelesaikan permasalahan yang diberikan, sehingga menjadi acuan. 


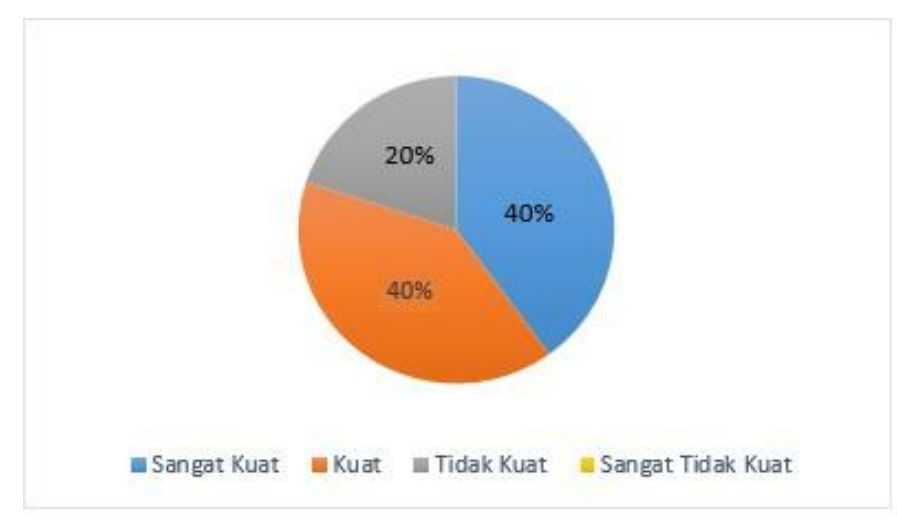

\section{Gambar 4. Respon siswa terhadap e-learing}

Indikator perhatian siswa belajar dengan menggunakan e-learning melalui google classroom rata-rata interpretasinya sebesar $40 \%$ dengan kategori sangat kuat, $40 \%$ dengan kategori kuat, dan $20 \%$ dengan kategori tidak kuat. Hal ini menunjukkan bahwa siswa yang memberikan perhatian terhadap pelajaran yang dilakukan secara daring kuat.

Berdasarkan hasil wawancara dan observasi dengan siswa, mendapatkan bahwa pembelajaran e-learning/daring membuat siswa memperhatikan pembelajaran. Dengan adanya pembelajaran secara online memberikan siswa perhatian penuh sehingga siswa tersebt senang dan tertantang untuk mengikuti pembelajaran daring tersebut di dalam classroom. Selain itu, setiap materi yang diberikan di classroom memudahkan didalam untuk memahaminya dengn cara membacanya secara berulang-ulang dan mengerjakan tugas atau kuis dengan tepat waktu sesuai dengan yang sudah ditentukam di google classroom.

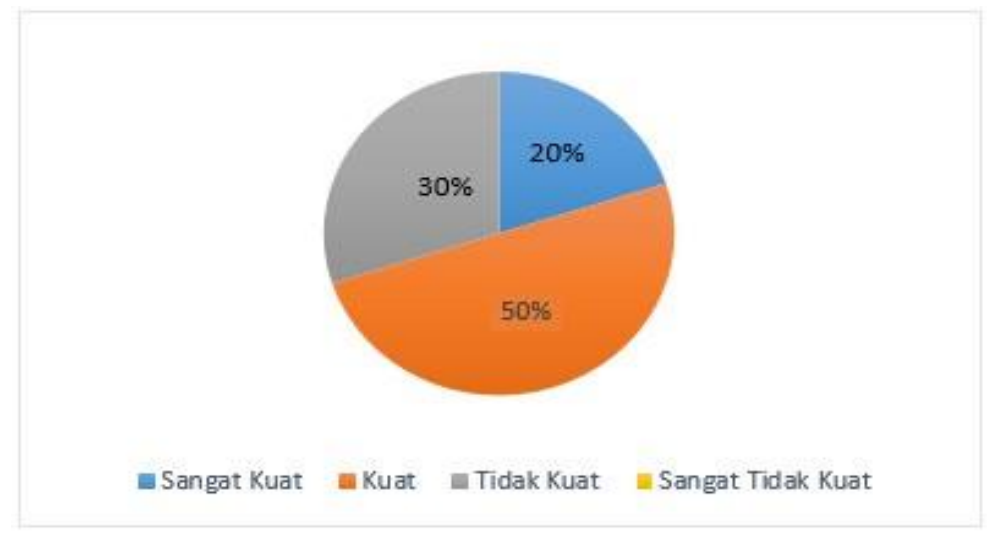

\section{Gambar 5. Respon Keterlibatan Siswa}

Indikator dalam pembelajaran dengan menggunakan e-learning melalui google classroom yaitu rata-rata interpretasi $20 \%$ dengan kategori sangat kuat, 50\% dengan 
kategori kuat, dan 30\% dengan kategori tidak kuat. Hal ini menunjukkan bahwa siswa tertarik ketika belajar dengan e-learning melalui google classroom.

Hasil wawancara dengan beberapa siswa menyatakan bahwa pada saat pembelajaran tatap muka siswa lebih banyak diam dan sulit untuk bertany terkait pembelajaran yang sedang berlangsung, sedangan pada saat diskusi online dengan menggunakan google classroom, siswa tampak tidak malu untuk bertanya mengenai kesulitan-kesulitan yang dialami pada materi yang diajarkan oleh guru. Dengan adanya diskusi online siswa tampak saling menanggapi pertanyaan dari temannya sehingga terjadinya keterlibatan aktif dalam pembelajaran.

\section{Simpulan}

Berdasarkan analisis data yang diperoleh dari hasil angket minat belajar siswa, dapat disimpulkan bahwa minat belajar siswa dengan menggunakan pembelajaran $e$ learning melalui google classroom dengan rincian rata-rata interpretasi kuat dengan rincian rata-rata interpretasi berdasarkan aspek-aspeknya, yaitu: 1) aspek perasaan senang sebanyak 60\% dengan kategori senang, 2) ketertarikan siswa sebanyak 50\% dengan kategori kuat, 3) perhatian siswa sebanyak 40\% dengan kategori sangat kuat, dan 4) terlibat aktif sebanyak 50\% dengan kategori kuat. Dari hasil hasil analisis tersebut, indikator perasaan senang paling tinggi dibandingkan indikator yang lainnya sebanyak $60 \%$.

\section{Referensi}

Dewi, P.S. \& Septa, H.W. (2019) Peningkatan Kemampuan Pemecahan Masalah dan Disposisi Matematis Siswa dengan Pembelajaran Berbasis Masalah. Mathema: Jurnal Pendidikan Matematika, 1(1), 31-39.

Djamarah, S. (2011). Psikologi Belajar. Jakarta: Rineka Cipta.

Gunawan, dkk. (2018). Pengembangan Kelas Virtual dengan Google Classroom dalam Keterampilan Pemecahan Masalah (Problem Solving) Topik Vektor Pada Siswa SMK untuk Mendukung Pembelajaran. Prosiding Seminar Nasional Pendidikan Matematik Etnomatnesia. 340-348.

Hamimi, L, Zamharirah, R. \& Rusydy. Analisis Butir Soal Ujian Matematika Kelas VII Semester Ganjil Tahun Pelajaran 2017/2018. Mathema: Jurnal Pendidikan Matematika, 2(1), 1-10

Iftakhar, S. (2016). Google Classroom: What Works and How?. Journal of Education and Social Sciences, 3(1), 12-18

Istiqomah, dkk. (2013). Penerapan Metode Blended Learning Berbasis ICT untuk Meningkatkan Minat dan Prestasi Belajar pada Mata Kuliah Ilmu Sosial Budaya Dasar (ISBD) di Prodi D-III Kebidanan FIK UNIPDU Jombang. JURNAL EDUHEALTH, 3(2), 103-113. 
Izenstark, A.\& Leahy, K.L. (2015). Google Classroom for Librarians: Features and Opportunities. Library Hi Tech News, 32 (9):1-3.

Kusuma, dkk. (2008). Analisis Perilaku Pengguna Sistem E-Learning.Universitas Gunadarma. Diseminarkan pada Seminar Ilmiah Nasional Komputer Dan Sistem Intelijen Auditorium Universitas Gunadarma.

Pappas, C. (2015). Google Classroom Review: Pros And Cons Of Using Google Classroom in e-Learning. Diakses 1 Mei 2017 dari https://elearningindustry.com/googleclassroom-review-pros-and-consofusinggoogle-classroom-in-elearning

Ridwan. (2006). Belajar Mudah Penelitian untuk Guru-Karyawan dan Peneliti Pemula. Bandung: Alfabeta Rosdakarya

Safari. (2003). Indikator Minat Belajar. Jakarta: Rineka Cipta

Saputra, V.H. \& Febriyanto, E. (2019). Media Pembelajaran Berbasis Multimedia Untu Anak Tuna Grahita. Mathema: Jurnal Pendidikan Matematika, 1(1), 15-23.

Septian, A., Agustina, D., \& Maghfrah, D. (2020). Model Pembelajaran Kooperatf Tipe Student Teams Achievement Division (STAD) Untuk Meningkatkan Pemahaman Konsep Matematika. Mathema: Jurnal Pendidikan Matematika, 2(2), 10-22.

Slameto. (2010). Belajar dan Faktor-faktor yang Mempengaruhinya. Jakarta: Rineka Cipta. Qomariah, S.S dan Ketut, R.S. (2016). Kualitas Media Pembelajaran, Minat Belajar, Dan Hasil Belajar Siswa: Studi Pada Mata Pelajaran Ekonomi Di Kelas X Iis Sma Negeri 12 Jakarta. Jurnal Pendidikan Ekonomi dan Bisnis, 4 (1),33-47.

Ulfa, M. (2019). Strategi Preview, Question, Read, Reflect, Recite, Review (PQ4R) pada Pemahaman Konsep. Mathema: Jurnal Pendidikan Matematika, 1(1), 15-23

Yaumi, M. (2007). The Implementation of Distance Learning in Indonesian Higher Education. Lentera Pendidikan : Jurnal Ilmu Tarbiyah dan Keguruan, 10(2), 196215 